
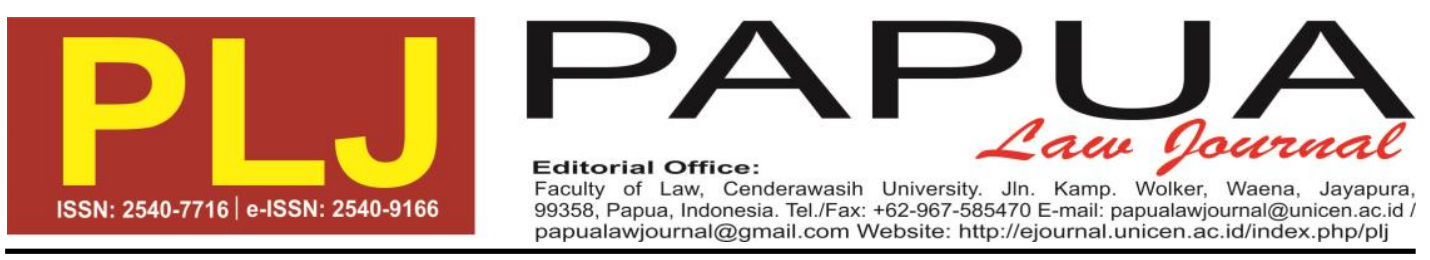

\title{
Koalisi Partai Politik Dalam Sistem Presidensil di Indonesia
}

\author{
Decky Wospakrik \\ Fakultas Hukum Universitas Cenderawasih \\ Jl. Kamp. Wolker, Waena, Jayapura, 99358, Papua, Indonesia \\ Tel./Fax.: +62-967-585470 E-mail: dwospakrik@gmail.com
}

\begin{abstract}
Abstrak: Koalisi Partai Politik Indonesia dalam sistem presidensil memberikan gambaran bahwa kekuasaan presiden bisa terkooptasi atau terbatas dikarenakan adanya kompromikompromi politik antarpartai politik dan Presiden yang tergabung dalam koalisi pemerintah. Koalisi yang dibentuk oleh pemerintah (Presiden beserta partai pengusung), dibagi berdasarkan komposisi kursi diparlemen dan dukungan partai selama Pilpres (Pemilu Presiden). Hal ini berimbas pada komposisi jumlah menteri di dalam kabinet pemerintah. Pembentukan koalisi diharapakan akan memberikan kestabilan terhadap agenda politik dan kerja presiden dikarenakan dukungan politik di parlemen yang kuat. Dengan demikian, solidnya koalisi dapat didasarkan pada kesamaan tujuan dan agenda politik bersama di antara koalisi partai politik.
\end{abstract}

Kata Kunci: Koalisi; Partai Politik; Sistem Presidensil

Abstract: Indonesian coalition of political parties in presidential system illustrates that the powers of the president can be co-opted or restricted because of their political compromises between the political parties and the President who are join members of the government's coalition. A coalition formed by the government (the President and the bearer party) is divided based on the composition of the seats in the parliament and the parties support during the election of president. It impacts the composition of cabinets ministers in government. Formation of the coalition is expected to provide stability towards the political agenda and president working which due to strong political support in parliament. Therefore, coalition solidarity can be based on shared objectives and common political agenda between the respective political parties.

Keywords: Coalition; Political Parties; Presidential Parties

\section{PENDAHULUAN}

Konstitusi Indonesia menegaskan bahwa Indonesia menganut sistem presidensial sebagaimana diatur dalam Pasal 4 Undang-Undang Dasar Negara
Republik Indonesia Tahun 1945 (UUD

1945) dan mulai diterapkan secara utuh pada pemilu 2004. Amendemen UUD

1945 telah berhasil mengantarkan pemerintahan Indonesia menjadi sistem 
presidensial murni. Ditandai pemilihan presiden dan wakil presiden secara langsung oleh rakyat. Apabila dibandingkan dengan sebelum amendemen UUD 1945, pemilihan presiden dan wakil presiden secara tidak langsung melalui Majelis Permusyawaratan Rakyat (MPR) yang banyak mengandung kelemahan dan distorsi ketika dipraktikkan sebelum amendemen UUD 1945. Sebelum amendemen UUD 1945, sistem pemerintahan Indonesia sering dikatakan sebagai sistem semipresidensiil.

Di Indonesia, sistem presidensiil dipadukan dengan sistem multipartai. Hal ini merupakan suatu realitas politik Indonesia yang menarik untuk dikaji secara akademis. Penerapan sistem pemilihan preseiden secara langsung sebagai penegasan sistem presidensil murni justru ditopang dengan multi partai.

Indonesia merupakan negara yang menempatkan koalisi sebagai bagian kekuatan Partai Politik (Parpol) dalam pertarungan merebut kekuasaan baik pada pemilihan presiden, gubernur, bupati/walikota. Koalisi yang diciptakan diantara partai politik di Indonesia tidak kaku dan cenderung liquid/cair, dikarenakan koalisi lebih mengutamakan pada kesamaan kepentingan bersama dalam memperoleh kekuasaan. Kekuatan koalisi yang dibangun partai politik pada pemilihan presiden berasal dari pada kekuatan penguasaan parlemen. Hal ini dilakukan oleh koalisi-koalisi dari masing-masing pendukung sehingga bukan hanya koalisi di ranah eksekutif namun legislatif juga diperkuat.

Dalam konteks Indonesia, dapat dilihat dalam pemilihan presiden baik saat Susilo Bambang Yudhoyono (SBY) jilid I dan II serta Jokowidodo Jusuf Kalla. Kekuatan partai politik terbagi antara partai politik yang ikut pemerintah dan partai politik diluar pemerintah (oposisi).

Koalisi tidak dapat dipungkiri adalah wujud dari pertarungan partai politik di Indonesia. Era pemerintahan SBY baik periode I (pertama) dalam pencalonan presiden SBY di dukung oleh partai politik (diluar Partai Demokrat) yang mana berkoalisi untuk merebut kekuasaan. Kekuatan koalisi dalam pemilihan presiden untuk periode ke II, koalisi dibentuk oleh Partai Demokrat dan partai-partai lain yang mendukung SBY sebagai Presiden untuk kedua kalinya. 
Hal ini terjadi juga pada saat koalisi dibentuk oleh PDIP dalam pemilihan presiden yang mengusung calon Presiden Jokowi. Pergeseran koalisi di Indonesia sangat cair antara partai politik. Dimana pada saat PDIP menjadi oposisi dalam pemerintahan SBY dan partai lainnya berada pada lingkaran kekuasaan pemerintahan dapat beralih menjadi kawan dalam persaingan perebutan kekuasaan. Dengan demikian koalisi menjadi bagian yang sangat penting untuk menggerakan mesin politik partai yang bertujuan menjaring kekuatan massa dalam pemilihan presiden.

\section{METODE}

Tipe penelitian hukum yang digunakan adalah penelitian hukum doctrinal atau penelitian hukum normatif, dimana melihat peraturan perundangan yang mempunyai keterkaikatan norma dalam analisis pembagian kekuasaan dalam koalisi partai politik pendukung pemerintah pada sistem presidensiil di Indonesia. Pendekatan penelitian ini menggunakan penelitian hukum doctinal, dengan pendekatan yang digunakan adalah pendekatan perundang-undangan (sta- tute aproach) dan pendekatan konseptual (conceptual approach). ${ }^{1}$

\section{PEMBAHASAN}

\section{Sistem Presidensial}

Sebelum perubahan UUD 1945, system presiden yang dianut oleh Indonesia adalah system pemerintahan semi presidensil-semi parlementer. Kemudian dengan adanya perubahan terdahap UUD 1945, meberikan penegasan sistem pemerintahan menjadi sistem presidensiil. Hal ini juga merupakan salah satu kesepakatan antara MPR tentang arah perubahan UUD 1945 yaitu sepakat mempertahankan sistem presidensiil sebagaimana terlampir dalam Ketetapam MPR Nomor. IX/MPR/1999.

Dalam Sistem pemerintahan presidensil atau presidential government atau "nonparliamentary executive system" atau "fixed executive system, disebut sebagai fixed executive, yang disertai pemilihan langsung akan memperkuat posisi presiden dalam hal berhadapan dengan legislative oleh karena dalam masa jabatan, Presiden sebagai kepala eksekutif secara politik tidak dapa dijatuhkan dari jabatannya.

1 Peter Mahmud Marzuki, (2005), Penelitian Hukum, Cetakan Pertama, Jakarta, Kencana, hal. 93-95 
Adapun ciri-ciri sistem pemerintahan presidensil adalah sebagai berikut: ${ }^{2}$

1. Sistem pemerintahan berpijak pada asas pemisahan kekuasaan merujuk pada teori Trias Politica dengan demikian adanya pemencaran kekuasaan diantara eksekutif, legislatif dan yudikatif. Kekuasaan eksekutif sebagai lembaga pelaksana Undanundang mempunyai kekuasaan untuk menerapkan undangundang tersebut kepada masyarakat atau pihak-pihak yang harus melaksanakan; kekuasaan legislatif sebagai pembuat undangundang yang nantinya dijadikan pedoman untuk berinteraksi baik secara kelembagaan maupun individu di dalam negara serta sebagai lembaga penyeimbang dan kontrol bagi pihak eksekutif; dan kekuasaan yudikatif, merupakan lembaga peradilan yang menjadi pilar untuk menegakkan undang-undang dengan segala konsekuensinya. Dengan demikian, masing-masing kekuasaan tersebut secara independent dan tidak dapat dipengaruhi dan mempengaaruhi diantara satu dan lainnya serta menjalankan fungsinya sesuai dengan peraturan perundangan.

2. Tidak ada pertanggungjawaban bersama antara Kepala Eksekutif (Presiden) dengan anggota kabinetnya (para menteri). Sebagai pembantu-pembantu Presiden, para menteri bertanggung jawab sepenuhnya kepada Presiden.

${ }^{2}$ HRT. Sri Soemantri M. (2014) Hukum Tata Negara Indonesia, Pemikiran dan Pandangan, Bandung: Rosdakarya, hal. 164166
Dalam hal ini menghindari posisi menteri bertangung jawab bukan hanya kepada Presiden tetapi juga kepada ketua partai politik (Parpol) menteri tersebut berasal. Dengan kata lain menghindari adanya matahari kembar, sehingga menempatkan menteri sebagai pembantu Presiden dan bertanggung jawab secara penuh kepada Presiden.

3. Kepala Eksekutif/Presiden tidak dapat membubarkan badan legislatif (parlemen/Congress) dan sebaliknya kepala eksekutif tidak harus mengundurkan diri (berhenti) jika tidak memperoleh dukungan mayoritas dari legislatif (parlemen, Congress). Presiden mempunyai masa jabatan 4 (empat) tahun. Bahkan dalam masa jabatan yang 4 empat tahun tersebut, Presiden tidak dapat dijatuhkan, kecuali melalui impeachment (pemakzulan) dimana Presiden telah melakukan pelanggaran hukum berupa pengkhianatan terhdap negara, korupsi, penyuapan tindak pidan berat lain atau perbuatan tercela. Proses impeachment melalui proses pembuktian tindakan tersebut di Mahkamah Konstitusi.

4. Sistem pemerintahan presidensiil juga disebut fixed executive system. Dari istilah tersebut Presiden mempunyai fixed term selama 4 (empat) tahun dikarenakan Presiden dipilih oleh rakvat secara langsung dalam suatu pemilihan umum sebagai konsekuensinya Presiden tidak bertanggung jawab kepada badan mana pun, hanya bertanggung jawab kepada rakyat. Pemberhentian Presiden dapat dilakukan dengan cara konstitusional 
melalui impeachmetjf.

Dengan demikian keseimbangan dalam hubungan Presiden dan Parlemen tergantung pada kekuatan yang dimiliki oleh presiden, yaitu kekuatan presiden tersebut dimiliki dari tiga sumber, pertama kekuasaan yang disebutkan dalam konstitusi, kedua adalah kekuatan partai pendukung presiden di parlemen dan ketiga adalah kekuatan legitimasi dalam pemilihan umum, presiden dipilih secara langsung oleh rakyat.

Jika kelemahan sistem presidensiil yang diterapkan di bawah UUD 1945 cenderung 'executive heavy' sudah dapat diatasi melalui pembaruan mekanisme ketatanegaraan yang diwujudkan dalam UUD 1945, maka ekses-ekses dalam praktik penyelenggaraan sistem pemerintahan presidensiil tidak perlu dikhawatirkan lagi. Keuntungan sistem presidensiil itu justru lebih menjamin stabilitas pemerintahan. $^{3}$

Sistem ini juga dapat dipraktikkan dengan tetap menerapkan sistem multipartai yang dapat mengakomodasikan peta konfigurasi

\footnotetext{
${ }^{3}$ Jimly Asshidiqie. (2005). Konstitusi dan Konstitusionalisme Indonesia. Jakarta: Konstitusi Press, hal. 60
}

kekuatan politik dalam masyarakat yang dilengkapi dengan pengaturan konstitusional untuk mengurangi dampak negatif atau kelemahan bawaan dari sistem presidensiil tersebut, yaitu ${ }^{4}, \quad$ Pertama, dalam sistem pemerintahan presidensiil ini, Presiden dan Wakil Presiden merupakan satu institusi penyelenggara kekuasaan eksekutif negara yang tertinggi di bawah Undang-Undang Dasar. Dalam sistem ini tidak dikenal dan tidak perlu dibedakan adanya kepala negara dan kepala pemerintahan. Kekuasaan dan tanggung jawab politik menjalankan pemerintahan negara berada di tangan Presiden (concentration of power and responsibility upon the President). Kedua, Presiden dan Wakil Presiden dipilih oleh rakyat secara langsung, dan karena itu secara politik tidak bertanggung jawab kepada Majelis Permusyawaratan Rakyat atau lembaga parlemen, melainkan bertanggungjawab langsung kepada rakyat yang memilihnya. Ketiga, Presiden dan/atau Wakil Presiden dapat dimintakan pertanggungjawabannya secara hukum apabila Presiden dan/atau Wakil Presiden 
melakukan pelanggaran hukum dan konstitusi. Dalam hal demikian, Presiden dan/atau Wakil Presiden dapat dituntut Pertanggungjawaban oleh Dewan Perwakilan Rakyat untuk disidangkan dalam Majelis Permusyawaratan Rakyat, yaitu sidang gabungan antara Dewan Perwakilan Rakyat dan Dewan Perwakilan Daerah, menurut prosedur hukum tata negara, sebelum proses hukumnya (pidana) dapat diteruskan untuk diselesaikan menurut prosedur peradilan pidana. Keempat, dalam hal terjadi kekosongan dalam jabatan Presiden atau Wakil Presiden, pengisiannya dapat dilakukan melalui pemilihan dalam sidang Majelis Permusyawaratan Rakyat. Akan tetapi, hal itu tetap tidak mengubah prinsip pertanggungjawaban Presiden kepada rakyat, dan tidak kepada parlemen. Kelima, para Menteri adalah pembantu Presiden dan Wakil Presiden. Menteri diangkat dan diberhentikan oleh Presiden, dan karena itu bertanggung jawab kepada Presiden, dan tidak bertanggungjawab kepada parlemen. Kedudukannya tidak tergantung kepada parlemen, namun karena pentingnya kedudukan para Menteri maka kewenangan Presiden untuk mengangkat dan memberhentikan Menteri tidak boleh bersifat mutlak, tanpa kontrol parlemen. Para menteri adalah pemimpin pemerintahan dalam bidangnya masing-masing. Merekalah yang sesungguhnya merupakan pemimpin pemerintahan sehari-hari. Oleh karena itu, para Menteri hendaklah bekerjasama yang seerateratnya dengan Dewan Perwakilan Rakyat dan Dewan Perwakilan Daerah. Keadaan ini menyebabkan dalam mengangkat Menteri, meskipun tidak mengikat, Presiden harus sungguhsungguh 'memperhatikan pendapat' Dewan Perwakilan Rakyat. Bahkan, susunan kabinet dan jumlah menteri yang akan diangkat, karena berkaitan dengan Anggaran Pendapatan dan Belanja Negara, ditetapkan oleh Presiden 'dengan persetujuan' Dewan Perwakilan Rakyat. Dengan demikian, Presiden tidak dapat mengangkat dan memberhentikan para Menteri dengan seenaknya. Keenam, untuk membatasi kekuasaan Presiden yang kedudukannya dalam sistem presidensiil sangat kuat sesuai dengan kebutuhan untuk menjamin stabilitas pemerintahan, ditentukan pula bahwa masa jabatan Presiden lima tahun dan tidak boleh dijabat oleh orang yang sama lebih dari dua masa jabatan. Di samping itu, 
beberapa badan atau lembaga negara dalam lingkungan cabang kekuasaan eksekutif ditentukan pula independensinya dalam menjalankan tugas utamanya. Lembaga-lembaga eksekutif yang dimaksudkan adalah Bank Indonesia sebagai bank sentral, Kepolisian Negara dan Kejaksaan Agung sebagai aparatur penegakan hukum, dan Tentara Nasional Indonesia sebagai aparatur pertahanan negara. Dari basis teoritis diatas, ide utama sistem presidensial pada dasarnya terletak pada presiden sebagai poros kekuasaan pemerintahan, tetapi penerapannya tetap dalam kendali rakyat dalam kerangka demokrasi.

Menurut Scott Mainwaring, sistem presidensial tidak otomatis menghambat kinerja dan stabilitas demokrasi suatu negara. Presidensialisme menjadi masalah kalau dikombinasikan dengan sistem multipartai. Berdasarkan hasil penelitian di 31 negara-negara Amerika latin, tidak ada satupun negara yang stabil demokrasinya dengan menerapkan sistem multipartai. Dari tahun 1967 - 1992, mainwarring menemukan bahwa semua negara yang menganut presidensialisme dan berhasil mempertahankan demokrasi ternyata menganut dwipartai (salah satunya Amerika Serikat). ${ }^{5}$

Sistem dua partai terbukti berjalan dengan baik di negara yang memiliki komposisi masyarakat homogen (social homogenity). Sementara Indonesia merupakan negara yang memiliki tingakat kemajemukan masyarakat yang sangat tinggi dan tingkat pluralitas sosial yang kompleks. Hal ini tercermin dalam sistem multipartai yang tergambar secara politik. Sistem presidensial di Indonesia seakan tidak diterapkan secara ideal karena sistem ini harus berkompromi dengan situasi politik multipartai. Implikasinya, presiden yang dipilih oleh rakyat secara langsung harus melakukan koalisi terhadap partai-partai yang terdapat di DPR dalam mengisi kabinet. ${ }^{6}$

Menurut Mahmud MD, sistem presidensil dapat di catat dengan adanya rinsip-prinsip sebagai berikut: ${ }^{7}$

1. Kepala negara menjadi Kepala Pemerintahan (eksekutif).

2. Pemerintah tidak bertanggung jawab kepada parlemen

\footnotetext{
${ }^{5}$ Hanta Yuda AR. (2010). Presidensialisme Setengah Hati - dari Dilema ke Kompromi, Jakarta: Gramedia, hal. 6

${ }^{6}$ Ibid.

7 Mexasasai Indra. (2011). Dinamika Hukum Tata Negara Indonesia. Bandung: Refika Aditama, hal. 128
} 
(DPR). Pemerintahan Parlemen adalah sejajar.

3. Menteri-menteri diangkat dan bertanggung jawab kepada Presiden.

4. Eksekutif dan Legislatif samasama kuat.

\section{Karekteristik Sistem Presidensil}

Karekteristik utama presidensil secara umum merupakan kebalikan dari karakteristik sistem parlementer. Karakteristik sistem presidensil, basis legitimasi presiden bersumber pada rakyat, bukan pada parlemen, seperti halnya sistem parlementer. Sistem presidensil ditandai dengan penerapan sistem pemilihan presiden dan wakil presiden secara langsung oleh rakyat dengan masa jabatan tetap. Dengan demikian presiden tidak bertanggung jawab kepada parlemen melainkan kepada rakyat. Kedua institusi ini bersifat mandiri dan dalam menjalankan fungsi checks and balances pemerintahan. Kedudukan presiden dalam sistem presidensial sebagai kepala negara dan kepala pemerintahan (singel chief executive). Presiden memiliki kekuasaan proregretif untuk membentuk pemerintahan dan berwenang mengangkat dan memberhentikan para memteri kabinet. $^{8}$

Karektiristi presidensial menurut Giovani Sartori dan Douglas V. Verney mengenai sistem presidensial. Sartori, mengemukakan tiga ciri; pertama, kepala pemerintahan (presiden dipilih secara langsung); kedua, dalam masa jabatannya presiden tidak dapat dijatuhkan parlemen; ketiga, presiden memimpin secara langsung pemerintahan yang dibentuknya. Sedangkan Verney mengajukan tiga karekteristik lainnya, pertama, kekuasaan eksekutif bersifat tidak terbagi (sole executive) jabatan kepala negara (head of the state) sekaligus kepala pemerintahan (head of government); kedua, tidak ada peleburan antara eksekutif dan legislatif, sehingga majelis tidak berubah menjadi parlemen dan presiden tidak dapat membubarkan atau memaksa majelis; ketiga, presiden (eksekutif) bertanggung jawab kepada konstitusi dan secara langsung kepada pemilih (rakyat). ${ }^{9}$

Dari beberapa karakteristik sistem presidensial yang ditulis olleh para ahli, pendapat Ball dan Peters termasuk yang paling jelas

\footnotetext{
8 Hanta Yuda AR., Op.cit., hal. 11

9 Hanta Yuda AR. Ibid., hal. 13
} 
memperhadapkan posisi presiden dengan lembaga legislatif. Dalam buku "Modern Politics and Government" dikemukakan karakter sistem presidensial sebagai berilkut: ${ }^{10}$

1. The president is both nominal and political head of state.

2. The president is not elected by the legislature, but is directly elected bby the total electorate. (There is an electoral college in the United States, but it is of political significance only in that each states votes as a unit and hence the system tends to disadvantage small parties).

3. The president is not part of the legislature, and he cannot be from office by the legislature except through the legal process of impeachment.

4. The president cannot dissolve the legislature and call a general election. Ussualy the president and the legislature are elected for mixed terms.

Ball dan Petters juga merumuskan empat karekteristik presidensialisme yang sejalan dengan alur logika di atas. Pertama, posisi presiden sebagai kepala negara sekaligus kepala pemerintahan; kedua, presiden tidak dipilih parlemen, melainkan dipilih langsung oleh rakyat; ketiga, presiden bukan bagian dari lembaga parlemen,

10 Saldi Isra. (2010). Pergeseran Fungsi Legislasi, Menguatnya Model Legislasi Parlementer Dalam Sistem Presidensial Indonesia, Jakarta: RajawaliPress, hal. 38 presiden tidak dapat diberhentikan parlemen, kecuali melalui mekanisme pamakzulan (impeachment); keempat, presiden tidak dapat membubarkan parlemen. ${ }^{11}$

Karakter yang dikemukakan Ball dan Peters tidak sebatas memperhadapkan presiden dengan lembaga legislatif, tetapi juga menegaskan bahwa eksekutif terpisah dari lembaga legislatif. Ketegasan itu menggambarkan bahwa lembaga kepresidenan dan lembaga legislatif merupakan lembaga negara yang paralel (the presidency and the legislature as two parallel structures). Posisi paralel ini menunjukan bahwa menjadi presiden tidak tergantung dari dukungan politik lembaga legislatif." Hal itu berbeda dengan sistem parlementer yang tidak memungkinkan membentuk pemerintah jika tidak ada dukungan mayoritas di parlemen. ${ }^{12}$

Heywood merumuskan beberapa karekteristik sistem presidensial, pertama, kepala negara dan kepala pemerintahan dijabat seorang presiden; kedua kekuasaan eksekutif berada ditangan presiden sedangkan kabinet yang terdiri atas menteri-menteri

\footnotetext{
${ }^{11}$ Hanta Yuda AR., Loc. Cit.

${ }^{12}$ Ibid.
} 
adalah pembantu presiden dan bertanggung jawab kepada presiden; ketiga, terdapat pemisahan personel yang ada diparlemen dan di pemerintahan. Menurut Mainwaring, sistem presidensial memiliki dua ciri utama, pertama, pemilihan kepala pemerintahan (presiden) diselenggarakan secara terpisah dengan pemilihan anggota parlemen, karena itu, hasil pemilu legislatif tidak menentukan kekuasaan pemerintah (eksekutif) secara langsung. Kedua, kepala pemerintahan dipilih untuk memerintah dengan periode waktu tetap (fixed term). ${ }^{13}$

Arend Lijpart mengemukakan tiga karekteristik sistem presidensial. Pertama, eksekutif dijalankan oleh satu orang (presiden). Kedua, eksekutif dipilih langsung oleh rakyat. Ketiga, masa jabatan presiden bersifat tetap dan tidak dapat diberhentikan berdasarkan pemungutan suara di parlemen. ${ }^{14}$

Dengan demikian dapat dilihat ada enam karekteristik dalam sistem presidensial di Indonesia pertama, basis legitimasi presiden berasal dari rakyat melalui pelembagaan sistem pemilihan presiden secara langsung oleh rakyat dengan masa jabatan tetap. Kedua, presiden bertanggung jawab secara langsung kepada rakyat, sehingga presiden tidak dapat dimakzulkan secara politis oleh parlemen, mekanisme pemakzulan melalui Mahkamah Konstitusi. Ketiga, relasi presiden dan parlemen bersifat mandiri dan setara, hal ini melalui pelembagaan mekanisme checks and balances (ketiga poin $1-3$ tersebut adalah struktur eksternal). Keempat, kekuasaan pemerintah tidak terbagi, yaitu pelembagaan kedudukan presiden sebagai kepala negara (head of the state) sekaligus sebagai kepala pemerintahan (head of government), presiden sebagai singel chief executive. Kelima, jabatan presiden dan wakil presiden merupakan institusi tunggal sebagai konsekuensi dari pelembagaan sistem satu paket pencalonan presiden dan wakil presiden dalam pemilihan. Keenam, hak proregatif presiden membentuk kabinet dilembagakan, konsekuensi posisi politik presiden sebagai pimpinan tertinggi eksekutif yang bersifat independen dan mandiri dari parlemen. (ketiga poin $4-6$

\footnotetext{
${ }^{13}$ Ibid., hal.14

${ }^{14}$ Ibid.
} 
tersebut adalah striktur internal presidensial). ${ }^{15}$

\section{Koalisi Partai Politik Indonesia}

Koalisi yang dibangun dalam

Pemilu Presiden bukan hanya kepentingan sesaat dalam pergelaran pemilu presiden namun koalisi akan dikembangkan dalam merebut kekuasaan dilegislatif. Bahkan koalisi akan memberikan tempat yang menguntungkan bagi partai politik yang mengusung presiden terpilih. Posisi keberadaan koalisi saat pemilu presiden dan akan berlanjut dalam pembentukan kabinet oleh presiden.

Pengalaman penggabungan partai dalam koalisi selama reformasi dan terakhir dalam pemerintahan SBY-JK (2004-2009) dan SBY-Boediono (20092014), mencatat adanya pengertianpengertian mengenai: ${ }^{16}$

1. Koalisi pencalonan Presiden dan Wakil Presiden pada pemilihan presiden ronde pertama;

2. Koalisi pencalonan Presiden dan Wakil Presiden pada pemilihan presiden ronde kedua;

3. Koalisi pembentukan kabinet pasca terpilihnya Presiden dan Wakil Presiden;

\footnotetext{
${ }^{15}$ Ibid.

16 Jimly Asshiddiqie. Makalah Institut Peradaban dan Gagasan Penguatan Sistem Pemerintahan. Disampaikan sebagai orasi ilmiah dalam rangka peluncuran Institut Peradaban di Jakarta, 16 Juli 2012
}

4. Koalisi pembentukan fraksi di DPR;

5. Koalisi pembentukan fraksi di MPR.

6. Koalisi pembentukan sekretariat gabungan partai pemerintah di luar struktur pemerintah atau pun struktur DPR.

Semua bentuk dan tahap koalisi tersebut, baik dalam proses pemilihan dan pembentukan pemerintahan maupun dalam pembentukan fraksi atau gabungan fraksi di DPR mengandung kelemahan sendirisendiri, sebagai akibat daya ikatnya yang tidak kuat dan didasarkan atas peraturan perundang-undangan yang berlaku. Bentuk-bentuk koalisi yang sama dapat berfungsi lebih kuat dalam sistem pemerintahan parlementer, karena para menteri kabinet bertanggung jawab kepada parlemen. Dengan demikian, koalisi di parlemen menjadi acuan yang menyebabkan koalisi dalam pemerintahan dapat berlangsung efektif. Hanya saja, dalam sistem pemerintahan parlementer, dinamika hubungan eksekutif-legislatif memang terbuka untuk diakhiri apabila timbul perbedaan pendapat antara pemerintah dan parlemen yang menyebabkan koalisi harus bubar, kabinet bubar dan bahkan parlemen juga dapat dibubarkan yang dilanjutkan 
dengan percepatan penyelenggaraan pemilihan umum. Sistem parlementer hal yang demikian justru dianggap sesuatu yang biasa. ${ }^{17}$

$$
\text { Realitas politik justru }
$$
dipertontonkan penuh anomali. Koalisi Indonesia Hebat menjadi kekuatan minoritas di DPR. Apakah kondisi ini masih sejalan dengan kaidah sistem kabinet presidensial dan amanat UUD 1945. Sebaliknya, hal ini merupakan realitas politik, kekuatan mayoritas di DPR dipegang oleh Koalisi Merah Putih (KMP) yang bukan merupakan koalisi pemerintah, kekuatan apa yang dimiliki oleh Presiden dalam menjalankan kekuasaannya dalam sistem kabinet demokratis presidensial agar bisa efektif menjalankan kekuasaan. $^{18}$

Koalisi dari sebuah kenyataan sistem multipartai lazimnya merupakan ciri utama dari sistem demokrasi parlementer. Mantan Ketua Mahkamah Konstitusi Jimly Asshiddiqie menyebut sebagai kegalauan, sebagaimana tecermin di berbagai media sosial tentang sistem pemerintahan Indonesia. Sehubungan dengan terpilihnya Joko

\footnotetext{
${ }^{17}$ Ibid .

${ }^{18} \mathrm{http}: / /$ print.kompas.com/baca/2015/11/20/Siste m-Presidensial,-Kedudukan-Kuat-Lazimnya-di-Ta
}

Widodo-Jusuf Kalla sebagai Presiden dan Wakil Presiden periode tahun 2014-2019, KIH menjadi koalisi partai pendukung pemerintah yang mendapat 208 kursi di DPR. Kekuatan KIH di DPR menjadi minoritas dan semua pimpinan kelengkapan lembaga di DPR ataupun MPR dikuasai oleh KMP. ${ }^{19}$

Skeptisisme terhadap presidensil multipartai pun kembali marak, termasuk PDI Perjuangan yang menjadi pemenang pemilu legislatif. Partai yang menjagokan Joko Widodo sebagai Calon Presiden ini berkehendak mengokohkan sistem presidensialisme dengan model koalisi politik yang ramping dan menghindari wacana bagi-bagi kekuasaan (power sharing) dalam proses pembentukan koalisi.

Berdasarkan hasil kajian Garda Bangsa $^{20}$ bahwa secara teoritik, sistem presidensialisme dianggap tidak kompatibel dengan sistem kepartaian majemuk (multipartai). Alasannya, yang pertama, sistem multipartai meniscayakan adanya koalisi pemerintahan karena tidak adanya partai mayoritas di badan legislatif. Koalisi

\footnotetext{
${ }^{19}$ Ibid.

${ }^{20} \mathrm{http}: / /$ news.okezone.com/read/2014/04/26 /62/976209/presidensialisme-multipartai-diindonesia-masih-efektif
} 
itu sendiri dianggap sebagai karakteristik dari sistem parlementer. Kedua, dengan adanya koalisi politik, maka kekuasaan presiden terpilih akan tersandera oleh kepentingan partai mitra koalisi, sehingga kekuasaan presiden dianggap melemah dan pemerintahan berjalan tidak efektif karena terlalu banyak kompromi. Ketiga, sistem multipartai atau sistem kepartaian yang terfragmentasi membawa kecenderungan munculnya presiden minoritas dengan dukungan legislatif yang lemah. Situasi ini dianggap akan menyebabkan sistem pemerintahan lumpuh. Agenda-agenda pemerintah dikhawatirkan akan mandeg dan hubungan eksekutif-legislatif terancam mengalami kebuntuan.

Dalam peraturan perundangan yaitu UU Nomor 42 tahun 2008 Tentang Pemilihan Presiden dan Wakil Presiden dilakukan secara langsung dan demokratis dimana rakyat diberi hak sepenuhnya menentukan Presiden dan wakil Presiden dalam pemilihan umum secara langsung. Pernyataan tegas tersebut dapat dilihat dalam Pasal 1 angka 2, 3 dan 4 serta Pasal 9 dilakuan secara langsung, bebas, umum dan rahasisa terhadap presiden dan wakil presiden yang diusung oleh partai politik dalam pemilihan anggota dewan perwakilan rakyat. Dengan demikian dalam peraturan perundangan telah membatasi dengan tegas bahwa pasangan calon pemilihan dilakukan secara langsung terhadap pasangan calon presiden dan wakil presiden harus memiliki perahu (partai politik pengusung). Dengan tidak memiliki partai politik pengusung bisa dikatan tidak memungkinkan bagi pihak yang ingin maju dalam pemilihan presiden dan wakil presiden tanpa diusung partai politik.

Pengusungan pasangan calon presiden dan wakil presiden tersebut dapat diusung oleh 2 partai politik atau gabungan partai politik yang memenuhi syarat dalam mengusung satu pasangan calon. Dalam Pasal 9 dengan tegas menyatakan pasangan calon presiden dan wakil presiden diusung oleh 2 (dua) partai politik atau gabungan partai politik peserta pemilu yang memenuhi syarat $20 \%$ kursi diparlemen atau memperoleh 25\% suara sah nasional dalam pemilihan anggota parlemen sebelum pemilihan presiden dan wakil presiden. Peryaratan dari Pasal 9 tersebut lebih menegaskan bahwa tidak semua partai politik dapat mengajukan pasangan 
calon presiden dan wakil presiden apabila tidak memiliki kursi dari hasil pemilu dengan syarat $20 \%$ atau $25 \%$ tersebut. Dengan demikian hanya partai politik yang memenuhi syarat tersebut dapat mengajukan 1 (satu) pasangan calon presiden dan wakil presidennya sendiri. Sehingga membuka ruang terjadinya gabungan atau koalisi partai politik dalam mengusung pasangan calon tersebut. Hal ini akan membuat koalisi partai politik dalam persaingan dalam pemilihan presiden dan wakil presiden membentuk koalisi partai politik sehingga dapat mengajukan pasangan calon yang diusung dalam pemilihan presiden dan wakil presiden.

Dengan persyatan dalam peraturan perundangan memberikan ruang adanya koalisi partai politik yang dapat terdiri dari 2 (dua) atau lebih dalam mendukung pasangan calon presiden dan wakil presiden. Koalisi yang terbentuk akan melahirkan kesepakatan bersama diantara partai pendukung pasangan calon dan akan mengikat pada saat hasil atau terpilihnya pasangan calon menang dalam pemilihan presiden dan wakil preseden. Kesepakatan dalam koalisi dapat melahirkan pembagian jatah menteri dari hasil dukungan selama pemilu presiden dan wakil presiden. Dalam hal presiden memiliki hak sepenuhnya dalam menentukan posisi menteri. Namun dalam koalisi tersebut tidak ada kepastian dalam hal mendukung pemerintah dalam jangka waktu 5 (lima) tahun dikarenakan kepentingan politik yang melatar belakangi hal ini dapat saja terjadi berhubungan dengan kebijakan dari presiden terpilih dalam menjalankan pemerintahan.

Relasi presiden dan parlemen dapat dipengaruhi oleh komposisi koalisi parpol, hal ini yang menjadi kekuatan dari presiden dalam berhadapan dengan parlemen. Bangunan relasi antara presiden dan parlemen dikarenakan koalisi parpol pendukung pemerintah menguasai parlemen sehingga memberikan perlindungan terhadap pemerintah dalam hal ini presiden dapat mewujudkan fungsi checks and balances diantara pihak eksekutif dan parlemen. Kompensasi dukungan dari parlemen tidak ada yang gratis atau cuma-cuma tetapi dapat dilihat dari koalisi parpol pendukung pemerintah yang mendapatkan jatah menteri dalam kabinet presiden. Posisi tawar yang menarik dari presiden terhadap parpol 
adalah posisi menteri yang tidak dapat ditolak parpol. Wujud bergabung dalam kekuasaan membuat jatah menteri menjadi bahan yang menarik bagi presiden dalam mencari dukungan parlemen. Jumlah kursi parpol adalah perimbangan dalam memberikan jatah kekuasaan kepada parpol.

Kekuasaan absolute presiden dalam menjalankan kekuasaannya Presiden dan dibantu oleh menteri yang diangkat dan diberhentikan oleh Presiden (Pasal 17 UUD 1945 amendemen ke-4 NRI) memberikan kekuasaan yang besar dalam posisi kekuasaan dalam menentukan para pembantunya. Dalam kenyataan posisi tawar antara Presiden dan parpol membuat kekuasaan yang absolute dari presiden dalam menentukan pembantunya dibatasi sehingga tidak dapat dengan absolute menentukan pembantunya. Terbatasinya kekuasaan presiden tersebut membuat posisi tawar parpol dalam mendapati kursi menteri menjadikan presiden tersandera dalam posisi tawar politik. Dikarenakan presiden membutuhkan dukungan secara politik dari parpol di parlement sehingga dengan demikian presiden menyandera dirinya dengan kepentingan parpol pendukungnya dalam koalisi diparlement.

Kursi parlemen yang dimiliki oleh parpol berbanding lurus dengan jumlah menteri yang diperoleh parpol tertentu dalam cabinet pemerintah. Sehingga koalisi pemerintah akan menjadi besar atau gemuk tergantung dari tawaran politik presiden kepada parpol pendukung diparlemen dengan menerima kesepakatan dalam mewujudkan bentuk koalisi dan tujuan yang akan dicapai dari presiden dengan mengakomodir kepentingan-kepentingan parpol. Terciptanya koalisi diparlemen yang stabil dan harmonis dapat menghindari konflik antara presiden dan parlemen. Dimana kekuatan oposisi tidak begitu besar dibandingkan kekuatan koalisi pemerintah. Dengan demikian presiden dapat mengendalikan parlemen dengan tidak ada ketakutan serangan dari parlemen terhadap program atau laporan pertanggung jawaban dari presiden. Ada hal dapat menjadi pengecualian terhadap parpol yang tidak memiliki kursi diparlemen tetapi dapat masuk dalam lingkaran kekuasaan pemerintah dikarenakan parpol tersebut merupakan pendukung dalam koalisi parpol preseiden dalam 
massa pemilu presiden dan wakil presiden.

Kedudukan parpol dalam koalisi pemerintah baik dikabinet dan parlemen memberikan gambaran adanya politik transaksional diantara pihak-pihak yang saling membutuhkan untuk memperoleh kekuasaan atapun mempertahankan kekuasaan. Hal ini tidak dapat dipungkiri, peluang dari peraturan memberikan jalan untuk membentuk kekuasaan dalam koalisi parpol yang berujung presiden dalam pusaran kekuasaan parpol koalisi.

Lebih lanjut merujuk dalam kajian yang dilakukan DKN Garda Bangsa $^{21}$ dari berbagai sumber kepustakaan, ada beberapa faktor yang membuat presidensialisme multipartai berjalan efektif. Pertama, kekuasaan presiden dan DPR dalam konstruksi konstitusi sama-sama kuat. Oleh karena sama-sama kuat, maka satu sama lain tidak bisa saling menafikan. Kedua, adanya mekanisme persetujuan bersama antara presiden dengan DPR. Sebagai ilustrasi dalam pembahasan RUU, baik pemerintah maupun DPR harus terlibat semenjak awal sampai akhir. Mekanisme ini memuluskan

\footnotetext{
${ }^{21}$ Ibid.
}

relasi eksekutif-legislatif karena keputusan tidak bisa diambil sepihak baik oleh presiden maupun DPR. Ketiga, organisasi dan proses pengambilan keputusan di DPR, yang sebagian besar mengharuskan keterlibatan pemerintah, selalu membuka jalan bagi terjadinya kompromi antara pemerintah dan DPR. Eksistensi fraksi dan alat-alat kelengkapan dewan (AKD) hampir selalu bisa menjembatani konflik antara eksekutif dengan legislatif. Keempat, adanya tradisi konsensus dalam pengambilan keputusan. Proses pengambilan keputusan lebih banyak didasarkan pada musyawarah mufakat, jarang sekali dilakukan voting atau pemungutan suara. Kalaupun terpaksa dilakukan voting, maka basis votingnya adalah fraksi (block voting), bukan voting suara individu anggota. Kelima, kapasitas kelembagaan DPR yang masih berada di bawah kapasitas kelembagaan eksekutif. Hal ini membantu melancarkan agenda pemerintah ke DPR. Keenam, adanya forum lobi dan konsultasi sebagai mekanisme informal, yang menjembatani konflik-konflik ranah formal dalam proses pengambilan keputusan. Beberapa faktor tersebut memungkinkan relasi eksekutif-legislatif di 
Indonesia berjalan lebih mulus dan efektif dibanding negara-negara lain seperti di Amerika Serikat atau Amerika Latin.

Koalisi politik yang solid selalu dibangun dengan orientasi strategis dan jangka panjang. Oleh karenanya diperlukan beberapa prasyarat dasar agar suatu koalisi politik benar-benar kuat dan solid, yaitu: Pertama, adanya kesepakatan mengenai platform dan agenda politik bersama di antara partaipartai yang berkoalisi. Kesepakatan platform politik saja tidak cukup untuk menjamin soliditas koalisi, karena perbedaan politik dalam tubuh koalisi justru sering muncul bukan karena perbedaan platform, melainkan karena perbedaan agenda politik dalam rangka merealisasikan platform. Dalam kasus pemerintahan koalisi SBY, misalnya, semua partai anggota koalisi sepakat dengan platform pemberantasan korupsi, tetapi soal bagaimana cara memberantas korupsi, masing-masing partai memiliki pandangan, cara dan agenda politik berbeda. Di tingkat inilah perbedaan muncul yang pada gilirannya mengurangi derajat soliditas koalisi. Kesepakatan mengenai platform dan agenda politik itu bukan saja akan mengokohkan soliditas koalisi, tapi lebih dari itu akan membuat koalisi bernilai strategis dan jangka panjang. Kedua, adanya pembagian kekuasaan atau power sharing yang secara relatif dianggap memuaskan oleh seluruh partai mitra koalisi. Pembagian kekuasaan itu bukan saja lazim dalam koalisi dengan sistem presidensialisme multipartai, lebih dari itu merupakan konsekuensi logis atau kebutuhan untuk menciptakan koalisi yang solid. Banyak negara yang menganut presidensialisme dengan sistem multipartai, pembagian kekuasaan di antara para anggota koalisi digunakan tolok ukur yang dianggap obyektif, seperti sistem skoring untuk jabatanjabatan strategis pemerintahan yang didistribusikan secara proporsional dan adil kepada mitra-mitra koalisi.

Perkembangan politik Indonesia menjadi terfragment koalisi partai politik dimana KIH mendapatkan tambahan dukungan dari PPP, Golkar, dan PAN, namun, tetap saja belum menjadikannya koalisi mayoritas di DPR. Sebaliknya, KMP merupakan pendukung Prabowo Subianto-Hatta Rajasa dalam perkembangannya kehilangan PPP, Partai Golkar secara faktual, dan PAN. Walaupun Partai 
Demokrat secara formal dimasukkan sebagai salah satu partai koalisi KMP, dalam garis kebijakan, Partai Demokrat lebih dianggap sebagai partai penyeimbang.

Koalisi Indonesia Hebat adalah koalisi partai politik di Indonesia yang mendukung Joko Widodo-Jusuf Kalla dalam Pemilihan Presiden tahun 2014. Koalisi ini terdiri dari PDIP, PKB, Partai NasDem, Partai Hanura, dan PKP Indonesia. Koalisi tersebut dideklarasikan pada saat acara Deklarasi Jokowi-JK pada 19 Mei 2014 di Gedung Djoeang, Jakarta. Terjadinya dinamika perpolitikan di Indonesia, menjadikan koalisi semakin kuat. Tercatat, pada bulan Oktober 2014, Partai Persatuan Pembangunan turut bergabung. Terakhir, pada bulan September 2015, Partai Amanat Nasional secara resmi ikut bergabung dan menyatakan keluar dari Koalisi Merah Putih. ${ }^{22}$

Koalisi Indonesia Hebat memiliki 208 kursi di DPR RI, yang terdiri dari 109 kursi dari PDI-P, 36 kursi dari Partai NasDem, 47 kursi dari PKB, 16 kursi dari Partai Hanura, sedangkan

22

www.id.wikipedia.org/wiki/koalisi_indonesia_h ebat
PKP Indonesia tidak mendapatkan satu kursipun di DPR karena ambang batas yang tidak mencukupi (syarat mendapatkan kursi DPR minimal suara nasional 3,5\%). Koalisi tersebut sangat minoritas di DPR dan semua pimpinan di DPR maupun MPR dikuasai oleh Koalisi Merah Putih. Pascapemilihan presiden 2014, Koalisi Indonesia Hebat telah mendapatkan pendukung baru yakni Partai Persatuan Pembangunan di parlemen maupun pemerintahan pada Oktober 2014 dan Partai Amanat Nasional pada bulan September 2015. Bergabungnya PPP dan PAN, maka kekuatan Koalisi Indonesia Hebat berbalik menjadi mayoritas di DPR, yaitu 295 kursi, dibandingkan dengan Koalisi Merah Putih yang memiliki 204 kursi dan Partai Demokrat yang memiliki 61 kursi. $^{23}$

\section{PENUTUP}

Koalisi Partai Politik di Indonesia tidak kaku atau dapat dikatakan cair, hal ini dikarenakan partai politik mencari persamaan tujuan dalam koalisi untuk memperoleh kekuasaan melalui cara yang dianggap demokratis yaitu pemilu. Pembentuk koalisi partai

\footnotetext{
${ }^{23}$ Ibid.
} 
politik dari era Susilo Bambang Yudhoyono (SBY) dan Jokowi, dapat terlihat dalam komposisi menteri yang tidak lepas dari kompromi politik koalisi pendukung pemerintah. Komposisi jatah menteri di kabinet berdasarkan peran serta dukungan partai politik pada massa pemilihan presiden dan bergabungnya partai politik setelah pemilihan presiden dalam lingkaran kekuasaan pemerintah dimana berkorelasi dengan komposisi jumlah kursi partai politik di parlemen dalam koalisi pemerintah.

Posisi Presiden yang kuat dalam sistem pemerintahan presidensial, memperoleh legitimasi kuat dikarenakan dipilih langsung oleh rakyat, namun dalam tataran implementasinya masih dibatasi oleh tekanan politik dari partai. Membentuk kompromi kekuasaan (power sharing) dalam kabinet yang dominan dari koalisi presiden diparlemen, dapat memberikan kekuatan kepada presiden dalam menempatkan posisi parlemen sebagai partner dalam mewujudkan relasi antara presiden dan parlemen setara dalam checks and balances. Di sisi lain dengan koalisi besar yang solid di parlemen, Presiden dapat menghindari ketakutan terjadinya impeachment terhadap dirinya. Pembentukan koalisi gemuk/besar kabinet, menteri-menteri hanya bertanggung jawab kepada presiden sehingga menghindari adanya matahari kembar bagi menteri dalam bertanggungjawab. Koalisi besar membutuhkan kekuatan kontrol dan ketaatan serta kesepahaman pembagian distribusi kekuasaan yang diberikan oleh Presiden kepada partai-partai koalisi yang solid dibangun orientasi strategis dan jangka panjang. Oleh karenanya diperlukan syarat dan kesepakatan bersama dalam hal agenda-agenda politik bersama partai koalisi dalam jangka panjang. Hal ini yang harus menjadi perhatian presiden apabila terjadi pergeseran kabinet yang akan berimbas kepada partai koalisi yang ujungnya bisa mengakibatkan ketidakstabilan dalam pemerintahan dan parlemen. Hal ini berimbas pada terganggunya kinerja kabinet pemerintah karena kegaduhan yang diciptakan parlemen.

Sistem presidensil Indonesia yang dipadukan dengan multi partai, memberikan ruang pembentukan koalisi partai politik Indonesia akan tetap berlanjut pada pemilihan presiden pada masa yang akan datang, yaitu koalisi antara partai-partai politik tidak 
melihat ideologi atau aliran-aliran partai sehingga bukan menjadi penghalang membentuk koalisi demi memperoleh kekuasaan.

\section{DAFTAR PUSTAKA}

AR, Hanta Yuda. (2010) Presidensialisme Setengah Hati - dari dilema ke kompromi, Jakarta: Gramedia.

Asshidiqie, Jimly. (2005). Konstitusi dan Konstitusionalisme Indonesia. Jakarta: Konstitusi Press.

Asshiddiqie, Jimly. Makalah Institut Peradaban dan Gagasan Penguatan Sistem Pemerintahan Disampaikan sebagai orasi ilmiah dalam rangka peluncuran Institut Peradaban di Jakarta, 16 Juli 2012.

Isra, Saldi. (2010) Pergeseran Fungsi Legislasi, Menguatnya Model Legislasi Parlementer Dalam
Sistem Presidensial Indonesia, Jakarta: RajawaliPress.

Indra, Mexasasai. (2011) Dinamika Hukum Tata Negara Indonesia, Bandung: Refika Aditama.

Marijan, Kacung. (2011) Sistem Politik Indonesia konsolidasi demokrasi pasca orde baru, Jakarta: Kencana.

Soemantri, Sri. (2014). Hukum Tata Negara Indonesia, Pemikiran dan Pandangan, Bandung: Rosdakarya.

http://print.kompas.com/baca/2015/11/

20/Sistem-Presidensial,-

Kedudukan-Kuat-Lazimnya$d i-T a$

http://news.okezone.com/read/2014/04/ 26/62/976209/presidensialism e-multipartai-di-indonesiamasih-efektif

www.id.wikipedia.org/wiki/koalisi_ind onesia_hebat 